POLITYKA ENERGETYCZNA - ENERGY POLICY JOURNAL

$2021+$ Volume $24 \star$ Issue $3 \uparrow 161-182$

DOI: $10.33223 / \mathrm{epj} / 142285$

Igbal Guliev $^{1}$, Ekaterina Krivosheeva ${ }^{2}$, Luiza AKIEva ${ }^{3}$, Petr KruZhilin ${ }^{4}$

\title{
The prospects of sustainable energy development in Latin America: prospects and parriers
}

ABSTRACT: The issues of green energy and sustainable development are one of the most discussed and most important today in face of the global challenges, such as global warming, greenhouse emissions, degradation of the ecology etc. In this regard, green energy is obviously a necessary part of the energy policy of a country. Still, economic crises and instability have led to the necessity to form a sustainable economy; hence the crossing of the two mentioned policies leads to the necessity to figure out what sustainable green energy is. The issues of green energy are very important for the developing economies, which are highly limited in financial resources. The countries of Latin America are among the ones which face significant issues in this sphere. The article is devoted to the formulation of this concept and to the proof that sustainable energy development is individual for every country. The scope of the research is the Latin American region, within the years since 2000. The authors conducted a regression analysis of the GDPs of several countries, namely, Bra-

$\triangle$ Corresponding Author: Igbal Guliev; e-mail: guliyevia@bk.ru

1 International Institute of Energy Policy and Diplomacy, MGIMO University, Russia; ORCID iD: 0000-0002-8667-8132; e-mail: guliyevia@bk.ru

2 International Institute of Energy Policy and Diplomacy, MGIMO University, Russia; ORCID iD: 0000-0003-4701-4242; e-mail: krivosheevakate@bk.ru

3 International Institute of Energy Policy and Diplomacy, MGIMO University, Russia; ORCID iD: 0000-0003-1662-3280; e-mail: magreg76@yandex.ru

4 International Institute of Energy Policy and Diplomacy, MGIMO University, Russia; ORCID iD: 0000-0001-7687-1177; e-mail: kruzhilin.p@inbox.ru

2021. The Author(s). This is an open-access article distributed under the terms of the Creative Commons Attribution-ShareAlike International License (CC BY-SA 4.0, http://creativecommons.org/licenses/by-sa/4.0/), which permits use, distribution, and reproduction in any medium, provided that the Article is properly cited. 
zil, Argentina, Peru and Colombia and their green energy sectors, and formulated conclusions on sustainable energy sources in these countries. The key findings include the proof of sustainable green energy sources for every researched country and the strategies for the improvement of these countries' renewable energy sector performance. The novelty of the article encompasses the methodology used and the concept of sustainable renewable energy.

KeYwords: Green energy, sustainable renewable energy, Brazil, Argentina, Peru, Colombia

\section{Introduction}

The issues of sustainable energy and the use of renewable energy in the economy of different countries have been discussed in many works and in general, this is the key topic of the discussion on all levels today. There are many approaches to what can be considered as green energy, renewable energy (Pimentel et al. 2002; Mohtasham 2015), but the issues of sustainability in the context of the development of the energy system of the new generation have been rarely raised.

Today Latin America is one of the most controversial regions, as it has both regional leaders, such as Brazil and the countries with rather weak economies, for instance, Bolivia or Paraguay, while Colombia has a unique economic model, which is tightly connected with tourism, and is supported by illegal drug exports (Loayza et al. 2019; Wainwright 2016). The overall performance of the economies of the continent can be characterized as unstable and hence the sustainability issues are the key topic for the future development of the continent. At the same time, these countries are focused on the US and Canadian market as the major export markets for their production. In this regard and taking into account the course of the former NAFTA establishment for protectionism (Abdulhamid 2019), the ecological characteristics of the Latin American products are highly important, just as the clean energy, providing possibility to produce carbon neutral goods.

The article focuses on sustainable energy for the specific countries of Latin America, which have been chosen as the most illustrative examples of the different approaches to the issue: Brazil, Peru, Argentina and Colombia. The named countries differ a lot in economic development as well, so it's a very important task to give interconnection between green energy development and economic development and the assessment of the rational decision making in the sphere of sustainable energy. In order to achieve this goal, the authors have conducted a regression analysis of the energy sector and GDP of the countries, made empirical model-based conclusions on the economic impact of the specific energy sources in the researched countries, based on the regression models, assessed the sustainability of green energy sources and developed recommendations, based on the economic conditions and the factors, revealed during the previous analysis. 


\section{Literature review}

The research on the sources in Scopus and Web of Science databases on the "sustainable energy" phrase gave an impressing quantity of about 3,500 articles in the Economics and Finance section, but the review of literature on the theme in 2019-2021 had no sign of dividing renewable energy and sustainable energy, despite the obvious necessity of such, expressed in (Dwipayana et al. 2021) where the authors have developed a special Sustainability Index, allowing to estimate the effectiveness of the Indonesian politics in green energy. The other interesting approach is expressed in (Oehlmann et al. 2021), where the authors concentrate on the underestimation of the positive external effects of green energy, proving they are higher than usually expected. The overall context leads to the conclusion that dividing sustainable and green energy hasn't been covered before, despite the abundance of logical prerequisites for it.

The development of green energy in Brazil is covered in (Gramkow and Anger-Kraavi 2019) and in (Bhandari and Sessa 2020), who both come to a conclusion that the green energy sector in Brazil is underdeveloped, despite the significant changes in the situation in recent years. Moreover, these articles point out the major problems of the Brazilian economic model, leading to the shortcomings in the energy sector development. The other article (Atkins 2020) covers such an issue as the industrialization of the Amazon basin, partially through the overuse of hydropower, while (Karp et al. 2021) examines the prospects of the ethanol diplomacy of Brazil, which is an extremely important instrument of the country external energy policy.

The Argentinean green energy sector is covered in a very scarce number of articles, most of them are of the beginning of the 2000-s, the comprehensive analysis of the state of being in the country is given in (Guzowski and Recalde 2008), the legislation framework is covered in (LaMarca 2011), so the basis for the research of the situation in the country is the analytical paper (KPMG 2019), which covers all the major risks and developments in the sphere.

Colombian green energy is covered in (Arias-Gaviria et al. 2019), where the author argues that the green energy policy in Colombia needs to concentrate on the spreading of green energy use to the far-away regions of the country, which don't attract many tourists. The technical analysis of the statistics on the Colombian green energy is given in (Pupo-Roncallo et al. 2020). The influence of biofuels on the country economy, partially on its energy imports is given in (Palacio-Ciro and Vasco-Correa 2020).

Green energy in Peru isn't covered in any article in general, but the situation with the biofuels is reviewed in (Klug et al. 2013) and in (Mzimela et al. 2018), stating that the major and the most suitable source of green energy in Peru is biofuel. In addition to that, the other article (Lucas et al. 2020) covers the innovations in the green-energy auctions, using Peru as an example (Lucas et al. 2020), proving them to be a very effective instrument of the green energy politics of the country. 


\section{Methodology}

The article is based on the comparison of the green energy and economically sustainable energy as two common, but not identical concepts. Green energy is any type of energy, generated from renewables, with no regard to the economic aspect - for instance, the EU considers nuclear energy as a non-green energy, but France insists, it's a sustainable energy source for its economy (WNN 2020; E. Velasquez et al. 2020). In Norway, where water resources are abundant, hydro energy is both green (as in any other country) and sustainable (Bakken et al. 2012). In this regard, sustainable energy concept includes two major characteristics: 1) little or no carbon trace in energy generation and the renewability of energy sources; 2 ) an insignificant negative impact, or positive impact on the economic development of the country in case the concrete type of energy is implied.

In order to assess the criterion of sustainability of energy in Latin America, the authors have put forward the hypothesis that if a specific type of energy influences GDP positively, it's sustainable. In order to test this hypothesis, the authors have conducted regression analysis in the following way: the GDP regression is based on the assessment of such parameters, as inward foreign direct investments flow ( $F D I)$, inflation (Infl), current account balance (TB), population $(P o p)$ and the supply of energy $(E S)$, the green energy regression is based on the same parameters and index variable, representing time $(t)$.

$$
G D P \sim F D I+\operatorname{Infl}+T B+P o p+E S+\text { const }
$$

$$
\text { Green energy } \sim F D I+I n f l+T B+P o p+E S+t+\text { const }
$$

The regressions are tested according to the common methodology by the $R^{2}$ value, $\mathrm{p}$-values and Durbin-Watson statistic in order to find the most adequate one.

The next step is the comparison of the exogenous variables - in case they are the same in both equations (the GDP equation and the equation of a specific green energy type), this type of green energy can be assessed as sustainable, as it is determined by the same factors, which drive the GDP and can be synergetic to its growth in case the empiric analysis demonstrates the non-contradictive results.

Based on the results received, the authors propose the optimal strategy for the sustainable energy development in the country. 


\section{Sustainable energy in Brazil}

The economy of Brazil is the most developed economy among the researched countries; hence the green energy development in Brazil is one of the most potentially financed sectors of green energy development in Latin America. Brazil is one of the first and most successful producers of the sugar cane (Hofsetz and Silva 2012) and has a significant territory, covered by tropical rainforests, which can be used in order to produce biofuels. In this regard, the energy system of the country can focus on this major direction, but the country is also rich in water resources. As a result, hydro energy can be produced in significant amounts as well. Moreover, the climate conditions of the country allow using solar panels effectively on the seashore, where the majority of the big cities are situated (D’Almeida Martins 2015; Quadrado 2021). As a result, the country is very rich in potential green energy resources, which can be used in order to fulfill the decarbonization goal of the country, equal to $43 \%$ of emission cuts by 2030 , which is a rather low value, compared to other dynamically developing economies (World Resources Institute 2020).

The other issue is the sustainability of the mentioned green energy developments for the economy of the country. Despite the fact that Brazil is the most dynamically developing economy of the region, it has several significant competitive advantages, such as cheap labor, relatively low standards of ecology regulations (not taking into account the regulations, concerning rainforests (Milaré et al. 2021; Neves 2016), and cheap energy resources. Hence, in case of the green energy massive introduction in the country economy, it can result in the rise of the energy costs, as the green energy is still more expensive than the conventional sources (IRENA 2019).

In addition to that, there is a significant factor, that undermines the Brazilian strive for the green and sustainable energy - the discovery of tight oil and shale oil in the country (The Oxford Institute for Energy Studies 2014) in 2005-2010. This introduced a possibility for a more energy-consuming policy, which has been the same from that time on.

The Brazilian energy sector in this regard, and taking into account the fact that the country hosts many industries, which require high volumes of energy, such as metallurgy, aviation, is quite heavily dependent on the conventional fuels. Let's refer to the Brazilian GDP model in order to figure out the major factors, contributing to its growth among the mentioned in the methodology section.

$$
G D P(\text { Brazil })=19,4495 \cdot F D I+2,3305 e+09 \cdot \text { Energy }
$$

The major parameters of adequacy for the model are the following: $R^{2}=0,98, \mathrm{DW}=2,41$ (Durbin-Watson statistic). Hence, the model is adequate and the two main factors, which determine the economic development of Brazil are FDI and energy demand. It is proven logically, as the FDI depict the foreign activity in the country, which is high, while energy demand - the possibility to enhance the transfer of foreign business to the country. In this regard, let's figure out what renewables can be used in order to support the development of the Brazilian economy. 
The regression for hydro energy is shown below.

$$
\text { Hydro }=1,603 e-07 \cdot F D I+0,00013 \cdot \text { Population }+1,274 e-07 \cdot B O P
$$

The model is adequate, $R^{2}=0.96, \mathrm{DW}=1.67$, which proves this statement. Hydro energy in the country has a vast potential because of the rich water resources and international partnership with the countries, which are on the front of the hydro energy production technologies through the mechanisms of BRICS and the New Development Bank of BRICS. The econometric model explains the current situation with hydro energy in the country - just as GDP, the energy sphere of Brazil, especially the one, which requires big investments (hydro energy) are to be financed either by foreign institutional investors, or foreign corporations because of the difficult economic situation in the country (Gouvea 2004; Barua and Samaddar 2021), the FDI factor in the model depicts it. Hydro energy provides about 13\% of energy in the country (IEA 2018), so the growth of the population is highly important for the hydroelectric stations, as their capacity should grow as well, especially in the circumstances of the unstable supply of oil to the country (Massi and Nem Singh 2018). The Balance of payment factor demonstrates the willingness of the Brazilian authorities to develop hydro energy, as it provides cheap energy in long run and stimulates the growth of energy dependent economy (Williams and Porter 2006). At the same time, the lack of financial resources, provided for the hydro energy development proves the necessity to refer to the foreign capital market.

When speaking of biofuels, Brazil is famous for its ethanol diplomacy and the high potential for its production. The high volume of sugarcane production and the overall high volume of organic debris, emerging form agricultural activities in the country form a strong basis for the generation of biofuels. The regression for it is given below.

Biofuels $=0,002 \cdot$ Population $+336,9 \cdot$ Energy $-6055,75 \cdot$ time -516007

$R^{2}=0.99, \mathrm{DW}=1.74$ are the adequacy parameters' values for the model. All of the growth of the Brazil population and the necessity to provide cheap and compatible energy in order to preserve the competitiveness of the Brazilian production on the international market leads to the auto growth of the ethanol production with the growth of the production of sugar and agricultural goods, which, in turn, correlates with population growth and exports. The energy demand factor in the model proves that the economy of Brazil highly depends on biofuels; moreover the shifts in energy demand tend to be covered by the change in ethanol production (Lopes et al. 2016). At the same time, it's notable that the carbon emission cuts, introduced in Brazil and the rainforests preservation are interconnected, as the majority of the Brazilian cuts in carbon emissions is gained by the cut down in rainforests destruction (Basso 2019), resulting in the absence of real technical improvement in the situation with ecology in Brazil. The result of the reduction of the rainforests destruction is the decrease in ethanol production, and due to the time-based approach to the realization of the rainforests protection plan, the time variable appears in the model. 
The most peculiar result is the regression on the solar and wind energy in Brazil. The country adopted a cautious approach to these renewables, as their massive introduction is costly and their effectiveness varies depending on natural conditions. The country, relying on energy as one of the drivers of economy can't promote unreliable energy sources.

Solar, wind $=33,74 \cdot$ Energy $+1,451 e-08 \cdot B O P-0,0015 \cdot$ Population $+2886,77 \cdot$ time +255823

The model is adequate $\left(R^{2}=0,98, \mathrm{DW}=1,82\right)$, so the factors, used in it are statistically significant. When speaking of energy demand in the private sector, especially the demand in rural regions and in far-away villages, wind electricity generators and solar panels provide high autonomy and enhance the possibilities of the rural development of isolated areas (Notton et al. 2011). Nonetheless, they are quite expensive, so only state funding of their promotion in the developing economies can boost their use by households. The growing energy demand in Brazil forces the country to promote solar and wind energy for households and for touristic sites as the clean, autonomous and nearly nonlimited source of energy, so the energy factor in the model describes the reserve role of solar and wind energy and their use in households and tourism. The high costs of such kinds of energy limit Brazil's possibilities for their promotion, majorly by the budget possibilities (the BOP factor). The general global green transition contributes to the cheapening of solar panels and wind energy generators, leading to the growth of the possibilities to buy them by the poorer citizens (time-factor).

The two peculiarities with this regression are the absence of FDI and negative value before the population factor. The institutional investors, such as the NDB of BRICS and the regional investors promote green technologies (Griffith-Jones and Leistner 2018), moreover, Brazil uses them and its absence in the model can be explained only by the higher significance of domestic investments as a more reliable and sustainable cashflow for the solar and wind energy development. The negative impact of population growth is also strange, as the transition to green energy of households is a logical development of the Brazilian energy sector, but it's possible that such result can be caused by the major growth of population in big cities, which are more effectively supplied by energy from conventional sources.

When the situation on the Brazilian energy market and its possibilities are revealed, let's figure out what kinds of energy are sustainable for Brazil. In order to do this, let's refer to table 1 .

Table 1 depicts that the Brazilian economy has the potential in the development of the all three energy sources; moreover, the effect of biofuels in the economic development of the

TABLE 1. The factors of the regression comparison

TABELA 1. Czynniki równania regresji

\begin{tabular}{|l|c|c|c|}
\hline \multicolumn{1}{|c|}{ GDP } & Hydro & Biofuels & Solar, wind \\
\hline FDI, positive & FDI, positive & Energy, positive & Energy, positive \\
\hline Energy, positive & & & \\
\hline
\end{tabular}


country is very high. Hence, all of them are sustainable in the context of economic development, but due to the path dependence biofuels are of the best economic effect, hydro energy is to be financed from abroad and solar and wind have their potential in rural and touristic areas, so the use of these sources in Brazil is to be regulated in such a way that the industries stimulate the development of hydro energy and majorly rely on it, the agriculture is to do the same with solar and wind energy, while the services sector combine sustainable energy sources, with a focus on biofuels and solar and wind energy.

\section{Sustainable energy in Argentina}

The development of the energy sphere in Argentina is tightly connected with the energy dependency of the country. Today, Argentina has several oil reserves discovered, but at the same time the demand for energy is growing, especially in the urbanized regions of the country, making it an importer of hydrocarbons. The other difficulty is the economic crisis, which significantly harmed the economy of the country; hence, the major difference of Argentina from Brazil in this regard is the high need for the capital resources in foreign currencies, as the national currency of the country is subject to high inflation (Palacio 2020).

At the same time, we can't miss out the fact that the green energy potential of the country is high. The constant winds in Central and Southern and high quantity of sunny days in the Northern regions along with the low quantity of big cities create the potential for the development of the green energy in the rural regions, while the overall moderate climate creates the need for sustainable and cheap heating, which can be provided by the use of biofuels in heating facilities. At the same time, it's notable, that although Argentina is a country that until recently has been fully dependent on hydrocarbon imports (Bekerman and Dulcich 2013), it seeks ways to overcome this dependence because of the bad economic situation and the ability to cut down the budget expenditures through the decrease of oil and gas imports.

Let's refer to the regression, characterizing the Argentinian GDP.

$$
\begin{aligned}
G D P(\text { Argentina })= & 7,12 \cdot F D I+33462 \cdot \text { Population }-4,549 e+09 \cdot \text { Inflation }- \\
& -1,274 e+10 \cdot \text { Energy }-3,894 \cdot B O P
\end{aligned}
$$

The regression is adequate $\left(R^{2}=0,96, \mathrm{DW}=2,69\right)$, the economic meaning of it is the following. The FDI is extremely important for the country, as it requires financial resources in order to revitalize its economy and to boost the development of the important infrastructure and energy projects, which have been stopped because of the crisis. The rural nature of the economy and low automatization rate in the country (Wane 2020) allow a conclusion on the positive effect of population growth to be made, as this allows for an increasing GDP without putting financial 
resources in the economy. The obviously negative effect of the inflation, which equaled $53 \%$ in 2019 of the national economy provides high risks, which make the investment in the country a very risky financial decision. Moreover, when speaking of the development of the rural economy with high inflation, the possibilities of such a country are highly limited, because the economic activity fades with the growth of prices and the rural population tends to become self-reliant and form closed communities, connected with barter. The investment projects in the country are also closing in such conditions, because the rate of return in real economy terms in long-run becomes negative. The energy sector in Argentina is quite undeveloped as well - the electricity grid works on its maximum in big cities (Schaube 2015), while its density is low and the countryside residents quite often don't have access to electricity at all. In this regard, the lack of energy resources limits the possibilities of the economic development of the country, so energy demand plays a negative role in the GDP growth. At the same time, the country trade in the researched period has been both positive and negative, so its influence on the economy of the country can be characterized as follows: the presence of exports is a significant boost to the economy of Argentina, but the volume of uncovered imports makes this advantage a small one.

As a result of the analysis, we can conclude that the economy of the country is very weak and the sustainable energy source in Argentina is either the one, which is extremely cheap, or the one, financed from abroad. Let's consider whether renewable sources of energy are sustainable in Argentinian realities.

$$
\text { Hydro }=8,262 e-05 \cdot \text { Population }-2,22 e-08 \cdot F D I-39,01 \cdot \text { time }
$$

The regression on hydropower is adequate $\left(R^{2}=0,99\right.$, DW $\left.=2,24\right)$, it demonstrates, that hydro resources are the main source of renewable energy in the country, as they provide the majority of renewable energy to the population. At the same time, the lack of investments (FDI factor) and the poor conditions of the existing facilities (time) allow to make a conclusion on the desperate need for capital and for the improvement in state politics, regarding this type of renewable energy.

While speaking of hydro energy in the country, it's notable, that the costs of the construction (reconstruction) of the hydro energy plants is very high, so the country will have to seek foreign investors, which in turn, will significantly increase the foreign debt of Argentina and in current conditions it's a bad blow to the country economy. In this regard, the focus on the development of the hydro resources in the country is a doubtful decision.

The other situation is with biofuels. This type of renewable energy resources won't contribute to the decarbonization of the country, but will provide stable supply of fuel for heating and vehicles. The regression for it is presented below.

$$
\text { Biofuels }=9,55 e-05 \cdot \text { Population }-2,701 e-08 \cdot B O P-19,656 \cdot \text { Energy }+9,18 \cdot \text { Inflation }
$$

It's adequate, but there are some factors, which are missing, which can be concluded from the DW statistic $\left(R^{2}=0,99, \mathrm{DW}=1,25\right)$. Just as in case of the GDP, the population of the country 
forms the demand for biofuels, as they are cheap and can be produced in non-industrial quantities in local communities. The negative impact of inflation and BOP bear the same nature, as in the regression for the GDP.

The possible missing factor can be the qualitive dummy variable, characterizing the biofuel regulation in the country. The government has amended the 2006 law on biofuels (Lamers et al. 2008) to give preferences to the small and medium producers, while the prices for the ethanol in the country are on the rise. In this regard, the politics of the Argentinian authorities clearly demonstrate the proposal to develop ethanol production by the local communities, hence predicting the long-run economic recession and the lack of affordable energy.

The other possible missing factor, derived from BOP is the ethanol export. Today only corn ethanol from Argentina has its export markets, while sugarcane ethanol is to be consumed in the country (Timilsina et al. 2013). This limitation can change the influence of biofuel production on the country economy.

When speaking of green energy in Argentina, we should mention that the country has vast potential, big demand, but lacks financial resources. The regression for wind and solar energy clearly demonstrates that tendency.

$$
\text { Solar, wind }=0,00015 \cdot \text { Population }+2,43 e-09 \cdot F D I-60,205 \cdot \text { time }-5573,06
$$

The regression is adequate $\left(R^{2}=0,75, \mathrm{DW}=1,81\right)$, it depicts that the population, especially rural, needs solar and wind energy, just as the fact, that the development of these types of energy highly depends on investments in the sphere, especially foreign ones. In the current condition the green energy production in Argentina falls due to the economic crisis and the inability of the numerous companies to realize the projects, which they have won on a RenowAr-3 tender (Bnamericas 2021). The current administration of the country is also quite doubtful about the Argentinian solar and wind energy development and tends to postpone it on the background of significant economic issues.

Taking the overall situation in Argentina into account, lets analyze the green energy sources by their sustainability characteristic (Table 2).

Taking the results of the analysis in Table 2 into account, the most sustainable renewable energy source in Argentina are biofuels, while solar and wind energy are less sustainable. Through

TABLE 2. The factors of the regression comparison

TABELA 2. Czynniki równania regresji

\begin{tabular}{|l|c|c|c|}
\hline \multicolumn{1}{|c|}{ GDP } & Hydro & Biofuels & Solar, wind \\
\hline FDI, positive & & & FDI, positive \\
\hline Energy, negative & & Energy, negative & \\
\hline Population, positive & Population, positive & Population, positive & Population, positive \\
\hline Inflation, negative & & & \\
\hline BOP, negative & & BOP, negative & \\
\hline
\end{tabular}


the results of the analysis, the country has high energy potential, but requires significant investments in order to have the possibility to develop it.

\section{Sustainable energy in Colombia}

Colombia has a very aggressive energy policy in the last several years - it pioneers the region in the pace of green energy facilities installation and has put forward an ambitious goal of a $51 \%$ cut in carbon emissions by 2030 (NDC 2020), introducing non-hydro power plants. The country has the high potential in hydro energy generation, namely, more than $65 \%$ of the energy in the country is generated by hydro energy plants, while the hydrocarbons are used in dry years. This system of energy generation is one of the most developed in Latin America, as it not only provides the country with clean, and not less important, cheap energy, but also has reserve capacities. The country has significant profits from tourism (Zuñiga-Collazos 2015) and oil exports, which create a firm base for the development of the country economy. At the same time, the factor of illicit activity, primarily drug trafficking and trade are the important factors in the development of the local economy too - drug trafficking both deters the economic growth of the country, as it provides significant risks, quite often these risks are unpredictable, but at the same time, generates cash flow, which boosts the disposable revenue of those connected with drug trafficking. Let's refer to the regression on the Colombian GDP.

$$
G D P(\text { Colombia })=6,045 \cdot F D I+2,297 e+09 \cdot \text { Energy }-1,068 e+10 \cdot \text { Inflation }
$$

This regression is adequate, but misses some factors $\left(R^{2}=0,99, \mathrm{DW}=1,47\right)$. The country's economy obviously grows, when the FDI volume is high, and the oil companies and touristic facilities boost it. The growth of the economy from the energy demand demonstrates the industrialization of the Colombian economy and the high contribution of the oil exports to the GDP (Melo-Becerra et al. 2020), while inflation decreases the economic potential. The inflation in the country is moderate and balances on the fringe of $3.5 \%$ in the past 5 years.

The factors, which could have improved the model, are tourism revenues, oil revenues' share in the budget and the average disposable income. They could have depicted the situation with the major sources of revenue and the main drivers of the country economy.

Taking the high significance of tourism for the country economy into account, clean energy becomes one of the priorities for the development of this industry, so let's discuss the regression on the major source of power in the country - hydro energy.

$$
\text { Hydro }=5,124 e-08 \cdot F D I+0,0003 \cdot \text { Population }-18,73 \cdot \text { Energy }-7618,79
$$


The model is adequate, $\left(R^{2}=0,92\right.$, $\left.\mathrm{DW}=2,33\right)$, moreover, it allows to make several conclusions on the country politics in the latest years. First of all, the abundance of FDI in the country has been massively used in order to develop hydro energy, so it formed a path-dependence for it, so this sphere of energy industry has a long-lasting potential for development, even in case the authorities of the country decide to concentrate more on the other spheres. The populations, just as the touristic sites, majorly rely on it, as the main source of energy, while the overall energy industry of the country is based on the two major pillars: hydro energy and oil. The higher is the demand for energy, the more will Colombia invest in other sources in the current circumstances of the non-hydro energy growth, so the policy and the will for diversification of the energy sector explain the negative coefficient before the energy variable in the model.

The biofuels in Colombia are cheap and quite widespread today, especially taking the recent growth of demand for biodiesel in the country into account. The local production is growing rapidly, as the country is liberalizing the production of biofuels (Colmenares-Quintero et al. 2020). The negative impact on the industry is presented by the often-changing blend policies and competition from the conventional fuel. Nonetheless, the demand is growing, just as the imports of biofuel to the country. The regression on the biofuels is presented below and is adequate $\left(R^{2}=\right.$ $=0,99, \mathrm{DW}=1,72$ )

$$
\text { Biofuels }=140,28 \cdot \text { Inflation }+30,23 \cdot \text { Energy }-7,45 e-08 \cdot B O P
$$

The positive influence of inflation describes the relatively lower shift in biofuel prices, compared with traditional diesel and gasoline. The positive influence of energy demand depicts the growing significance of the biofuels on the industrial demand for energy and partially on the rural communities. Biofuels are imported to Colombia from Brazil and Argentina, hence, the higher the imports, the more the competition between the local and foreign production. Taking the high potential of the Brazilian biofuels industry into account, the competitiveness of the Colombian producers is low, in this regard, high imports decrease the local production.

The most promoted in the recent years renewables sector in Colombia is solar and wind energy. It can boost the energy industry in the country, especially taking the similar actions, taken in UAE (which has similar economy constitution by industries) into account, although this is quite expensive.

The regression on solar and wind power in Colombia is presented below.

$$
\text { Solar, wind }=2,049 e-10 \cdot F D I+5,776 e-08 \cdot \text { Population }
$$

The regression is adequate, but misses some factors $\left(R^{2}=0,90, \mathrm{DW}=1,41\right)$, the positive role of FDI and the cooperation between the Latin American countries is obvious, but Colombia receives significant investments from the NAFTA countries too, which pursue the green economy values, in this regard, the FDI in green energy from solar and wind have a special meaning for the companies from these countries. The growth of population and the arriving tourists also has a positive effect on this energy sector as the cashflow and the growing demand for clean energy 
can be satisfied in the local communities and by small companies by introducing green energy facilities.

In order to figure out which sources of energy are sustainable in Colombia, let's refer to Table 3.

TABLE 3. The factors of the regression comparison

Tabela 3. Czynniki równania regresji

\begin{tabular}{|l|c|c|c|}
\hline \multicolumn{1}{|c|}{ GDP } & Hydro & Biofuels & Solar, wind \\
\hline FDI, positive & FDI, positive & & FDI, positive \\
\hline Energy, positive & & Energy, negative & \\
\hline Inflation, negative & & & \\
\hline
\end{tabular}

Table 3 demonstrates, that none of the researched energy sources has a special sustainability effect on the economy of the country, the empirical study showed that none of them have a negative impact, so in such circumstances, they are all sustainable energy sources in Colombia.

\section{Sustainable energy in Peru}

When speaking of green energy in Peru, we should be brief, as the overall state of being with green energy in the country is rather weak. The goal of the country is to achieve $60 \%$ of energy generation from green sources by 2025 (The Energy Year 2014). The potential of the country is rather big, especially when speaking of solar and wind energy (Flanders investment \& trade market survey 2020). At the same time, the legislative framework doesn't provide any special conditions for green energy producers, so the country depends on conventional energy sources. The following regression is adequate $\left(R^{2}=0,97, \mathrm{DW}=1,79\right)$ and reflects the Peruvian GDP.

$$
\begin{gathered}
G D P(\text { Peru })=2,027 \cdot F D I+16796,7 \cdot \text { Population }+4,294 e+09 \cdot \text { Energy }- \\
-1,705 \cdot B O P-4,458 e+11
\end{gathered}
$$

The economy of Peru is based on exports of agricultural goods and on the mining activities, which are highly attractive for foreign investments, while agricultural development is dependent on the population. The need for energy in this context puts forward energy as one of the major factors of economic development. The non-ability to produce industrial goods forces the country to import them, making it dependent on imports. 
Let's review the situation with hydro energy in Peru.

$$
\text { Hydro }=0,00021 \cdot \text { Population }-1,782 e-08 \cdot F D I-4096,48
$$

The regression is adequate $\left(R^{2}=0,91, \mathrm{DW}=1,72\right)$, it reflects the long-run positive experience of the use of hydro energy in Peru, especially by the households and in farfetched regions, for instance in the mountain regions. The government has recently concentrated on the possibilities of investments in gas, so the ones in hydro energy have fallen, substituted (World Bank 2010).

Biofuels are a cheap and easily transported source of energy. The regression for them looks the following way and is adequate $\left(R^{2}=0,96, \mathrm{DW}=1,69\right)$.

$$
\begin{gathered}
\text { Biofuels }=1,971 e-08 \cdot F D I+0,0001 \cdot \text { Population }+22,19 \cdot \text { Energy }- \\
-1,622 e-08 \cdot B O P-65,5 \cdot \text { time }
\end{gathered}
$$

The need for investments in the context of the developing economy of Peru, just as the influence on all energy sectors because of the substitution effect provide biofuels a significant effect on the Peruvian economy. The imports of biofuels from other countries provide the negative coefficient before BOP, while the demand for them by households a positive one before the Population variable.

The development of solar and wind energy in Peru is described by the following regression.

$$
\text { Solar }, \text { wind }=10,98 \cdot \text { time }+1,018 e-06 \cdot \text { Population }-1,474 e-08 \cdot F D I
$$

It's adequate $\left(R^{2}=0,85, \mathrm{DW}=1,67\right)$, and allows the following conclusions to be formed: the solar and wind energy in Peru will develop with time, but the only real driver for it is the private sector. They are underinvested and the green investments in the country are substituted by investments in other energy sectors.

The sustainable energy sources in Peru are described in Table 4.

TABLE 4. The factors of the regression comparison

Tabela 4. Czynniki równania regresji

\begin{tabular}{|l|c|c|c|}
\hline \multicolumn{1}{|c|}{ GDP } & Hydro & Biofuels & Solar, wind \\
\hline FDI, positive & & FDI, positive & \\
\hline Energy, positive & & Energy, positive & \\
\hline Population, positive & Population, positive & Population, positive & Population, positive \\
\hline BOP, negative & & BOP, negative & \\
\hline
\end{tabular}


The biofuels seem to be the most sustainable renewable energy source in Peru, while hydro and solar and wind are less sustainable, but taking the path dependence for the hydro energy into account, it can be named sustainable as well.

\section{Discussion}

The massive analysis of the econometric models' factors for the green and sustainable energy development in the researched countries allows to propose recommendations for the sustainable energy development for every country, based on the revealed facts on renewable energy sustainability.

\section{Brazil}

- The sustainable energy sources in Brazil are numerous, hence the major task of the country is to find ways to finance them from different sources: hydro energy is to be financed through the development institutions, for instance, the NBR or the World Bank Group credits, the solar and wind energy through the taxation of the agricultural producers (requires amendments in the Brazilian tax system) and partially through the introduction of the tax for the use of former rainforest land, while biofuels development has to be supported by the government expenditures and special credits;

\ The biofuels diplomacy is to be revived, especially taking the demand for biofuels from Argentina, Colombia and Peru, and the export possibilities Brazil can restore its position of the global biofuels' leader into account, and can attract significant FDI in this sphere;

$\checkmark$ Brazil has to introduce new quality of indicators for decarbonization and a green energy policy efficiency: the contemporary ones don't see the difference between the stop of deforestation and real changes in carbon emissions. The authors suggest to introduce corrective coefficients, for instance:

$$
\left\{\begin{array}{c}
\text { correct }=F C \cdot \Delta F S \\
\Delta C E_{r}=\Delta C E_{e}+\text { correct }
\end{array}\right.
$$

Where correct is the correction coefficient, FC - is the constant value of carbon emissions absorption by a hectare of rainforest (may be in between 100 and 250 metric tons of $\mathrm{CO}_{2}$ per hectare a year, according to different sources (Anna 2012; FAO 2021; Brack 2019), FS stands for the surface of forests in Brazil, $\mathrm{CE}_{\mathrm{r}}$ - are the real (corrected) cuts in carbon emissions, $\mathrm{CE}_{\mathrm{e}}$ are the estimated volume of $\mathrm{CO}_{2}$ cuts;

$\checkmark$ Brazil can introduce a special commission (hotel tax) for tourists, such as is the Russian practice (Fontana and Lagutin 2018), which is to be used in the development of solar and wind energy; 
$\checkmark$ Brazil can enhance its program for public-private partnerships in green energy development in favor of small energy facilities for local communities, so they are connected in a single grid;

$\checkmark$ Brazil should enlarge the scope and capacity of its energy grid, that can be financed from the same sources, as the hydro energy development and from the cooperation with the Chinese energy companies, seeking ways to expand to new markets (Márquez 2019);

$\checkmark$ introduce an impact-based model of taxation for companies, working in the Amazon region the higher the carbon trace, the higher the tax;

$\downarrow$ Brazil shouldn't focus on any single energy source, as they are all sustainable for its economy.

\section{Argentina}

$\downarrow$ imply special tax preferences for households, running of solar and wind energy, while introducing a higher tax for energy companies, providing energy, generated from conventional sources;

$\downarrow$ use the additional profits from the new tax in order to conduct the reconstruction of hydropower plants, but not invest in the growth of their quantity;

$\downarrow$ liberalize the system of biofuel trade and production, introduce loyal blends for SMEs, especially in the agricultural sector;

$\downarrow$ introduce a tax credit for the local communities, producing biofuel on a small and medium scale;

$\checkmark$ build up the capacity and quality of the electric grid, especially in the big cities and industrial regions by providing special tax conditions for foreign energy companies;

$\checkmark$ build up the quality of electric grid in rural areas by crediting local communities and by offering special conditions for the domestic energy companies, especially in the sphere of taxes;

$\downarrow$ pay special attention to biofuels and solar and wind energy.

All of the above mentioned can work properly only in circumstances of a more stable economy of the country, which is quite a challenge for the country administration today.

\section{Colombia}

$\downarrow$ provide special agreements with companies, producing energy from sustainable sources, based on direct trade between them and the public energy grid;

$\downarrow$ provide special tariffs regulation for sustainable energy, so that its price doesn't exceed the price of energy from other sources by state subsidies;

$\downarrow$ introduce a tax maneuver, when the taxes from oil exports and hydrocarbon imports are used in order to reconstruct the existing hydro energy plants;

$\checkmark$ support the activity of non-governmental organizations (and create new ones), which have a mandate to function on the territory of the US and Canada, in this way building up private financing of solar and wind energy development;

$\checkmark$ introduce a special tourist commission, which is to be used to stimulate the development of the solar and wind energy use in the most visited by tourists regions;

$\checkmark$ introduce an impact-based model of taxation for companies - the higher is their impact on the non-hydro energy carbon emission cuts, the greater the tax cut for them and the contrary; 
$\checkmark$ develop all the green energy sources simultaneously and equally with special attention on hydro energy and solar and wind energy (requires change in policy according the primary role of the latter).

\section{Peru}

$\downarrow$ introduce special taxation for the green energy companies;

$\downarrow$ introduce special tax benefits for the companies and households, running of solar, wind or biofuels;

$\downarrow$ create a clear and stable legislative framework for the green energy development and use in the country;

$\checkmark$ use the credit mechanisms of the World Bank Group and the financial cooperation in APEC for the stimulation of the sustainable energy development;

$\checkmark$ focus on biofuels, while in case financial possibilities are abundant, develop solar and wind energy.

\section{Conclusion}

The major conclusions of the article are the following. Firstly, sustainable energy and green energy are not the same. While the parameters of green energy are unified and can be analyzed in general with little or no regional and national specific, sustainable energy characterizes what kinds of green energy are the least harmful or the most beneficial for the country (region) economy.

Secondly, the sustainable energy sources in Brazil encompass all the green energy sources, so all of them should be developed, but because of the misleading decarbonization statistics, Brazil has to enhance its approaches to the decarbonization and sustainable energy development, especially in the sphere of reviving ethanol diplomacy.

Thirdly, sustainable energy in Argentina should be cheap and easy to transport, so biofuels are the most suitable energy source. At the same time solar and wind energy can be generated locally on the entire territory of the country, so they can suit the mentioned criterions in case the authorities of the country provide support for their development. In order to do that, extensive financial measures are needed, which can't be implied when country is in the crisis.

Fourth, Colombia has gone further than any other country of the Latin America on the road of green energy development. Just as in Brazil, all the green energy sources are sustainable in the country, so in order to fulfill the ambitious goals, the country has to interconnect the financial flows from oil exports and tourism as the most developed and profitable sectors of the economy and the green energy development. In addition to that, the country should pay equal attention to the solar and wind energy and hydro energy.

Fifth, Peru has to develop a clear approach to green energy, as in the current state the development of sustainable energy in the country is nearly impossible. The only sources of 
sustainable energy in Peru are biofuels, but there is no clear stimulation or framework for their production.

Sixth, the researched countries today don't have a clear financial mechanism for the financing of the green energy, so its development is a primary task for all of them.

\section{Reference}

ABDULhamid, S. and SyED, A. 2019. Rise of trade protectionism: the case of US-Sino trade war. Transnational Corporations Review 11(4), pp. 279-289, DOI: 10.1080/19186444.2019.1684133.

Analysis. Problems and Perspectives in Management, 2(4). [Online] https://www.businessperspectives. org/images/pdf/applications/publishing/templates/article/assets/1034/PPM_EN_2004_04_Gouvea.pdf [Accessed: 2021-07-10].

Arias-Gaviria et al. 2019 - Arias-Gaviria, J., Carvajal-Quintero, S.X. and Arango-Aramburo, S. 2019. Understanding dynamics and policy for renewable energy diffusion in Colombia. Renewable Energy 139, pp. 1111-1119, DOI: 10.1016/j.renene.2019.02.138.

ATKINs, E. 2020. Contesting the 'greening' of hydropower in the Brazilian Amazon. Political Geography 80, 102179, DOI: 10.1016/j.polgeo.2020.102179.

Bakken et al. 2012 - Bakken, T.H., Sundt, H., Ruud, A. and Harby, A. 2012. Development of Small Versus Large Hydropower in Norway - Comparison of Environmental Impacts. Energy Procedia 20, pp. 185-199, DOI: 10.1016/j.egypro.2012.03.019.

Barua, A. and SamadDar, M. 2021. Brazil Monetary policy turns its gaze on inflation. [Online] https:// www2.deloitte.com/us/en/insights/economy/americas/brazil-economic-outlook.html [Accessed: 2021$-07-10]$.

BAsso, L. 2019. Brazilian energy-related climate (in) action and the challenge of deep decarbonization. Revista Brasileira de Politica Internacional 62(2), DOI: 10.1590/0034-7329201900202.

Bekerman, M. and Dulcich, F. 2013. The international trade position of Argentina. Towards a process of export diversification? Cepal review 110. [Online] https://www.cepal.org/sites/default/files/publication/files/36999/RVI110BekermanDulchich_en.pdf [Accessed: 2021-07-10].

Bhandari, R. and Sessa, V. 2020. Energy in agriculture in Brazil. Revista Ciencia Agronomica 51(5), pp. 1-11, DOI: $10.5935 / 1806-6690.20200098$.

Bnamericas 2021. Argentina begins to cancel renewable energy projects. [Online] https://www.bnamericas. $\mathrm{com} / \mathrm{en} /$ features/argentina-begins-to-cancel-renewable-energy-projects [Accessed: 2021-07-10].

Brack, D. 2019. Forests and Climate Change. [Online] https://www.un.org/esa/forests/wp-content/ uploads/2019/03/UNFF14-BkgdStudy-SDG13-March2019.pdf [Accessed: 2021-07-10].

Colmenares-Quintero et al. 2020 - Colmenares-Quintero, R.F., Rico-Cruz, C.J., Stansfield, K.E, Colmenares-Quintero, J.C. and Yibing L. 2020. Assessment of biofuels production in Colombia. Cogent Engineering 7(1), DOI: 10.1080/23311916.2020.1740041.

D'Almeida Martins, R. 2015. Coastal Cities and Climate Change: Urbanisation, Vulnerability and Adaptive Capacity on the Northern Coast of the São Paulo State, Brazil. [Online] https://core.ac.uk/download/ pdf/199430668.pdf [Accessed: 2021-07-10].

Dwipayana et al. 2021 - Dwipayana, Garniwa, I. and Herdiansyah, H. 2021. Sustainability Index of Solar Power Plants in Remote Areas in Indonesia. Technology and Economics of Smart Grids and Sustainable Energy 6(2), pp. 1-14, DOI: 10.1007/s40866-020-00098-0.

FAO 2021. Climate change and forests. [Online] http://www.fao.org/3/y0900e/y0900e06.htm [Accessed: 2021-07-10]. 
Flanders investment \& trade market survey 2020. Peru's renewable energy market. [Online] https://www. flandersinvestmentandtrade.com/export/sites/trade/files/market_studies/Energy\%20industry\%20 in\%20Peru-2020.pdf [Accessed: 2021-07-10].

Fontana, C. and Lagutin, I. 2018. Tourist Taxes in Italy and Russia. Russian Law Journal 6(1), pp. 83-99, DOI: $10.17589 / 2309-8678-2018-6-1-83-99$.

GouveA, R. 2004. Challenges Facing Foreign Investors in Brazil: A Risk Analysis. Problems and Perspectives in Management 2(4). [Online] https://www.businessperspectives.org/images/pdf/applications/publishing/templates/article/assets/1034/PPM_EN_2004_04_Gouvea.pdf [Accessed: 2021-07-10].

Gramkow, C. and Anger-Kraavi, A. 2019. Developing Green: A Case for the Brazilian Manufacturing Industry. Sustainability 11(23), 6783, DOI: 10.3390/su11236783.

GRIFFITH-JONES, S. and LEISTNER, S. 2018. Mobilising capital for sustainable infrastructure: the cases of the AIIB and the NDB. [Online] https://www.die-gdi.de/uploads/media/DP 18.2018.pdf [Accessed: 2021-07-10].

GuzowsKi, C. and ReCALDE, M. 2008. Renewable energy in Argentina: Energy policy analysis and perspectives. International Journal of Hydrogen Energy 33(13), pp. 3592-3595, DOI: 10.1016/j.ijhydene.2007.11.032.

Hofsetz, K. and Silva, M.A. 2012. Brazilian sugarcane bagasse: Energy and non-energy consumption. Biomass and Bioenergy 46, pp. 564-573, DOI: 10.1016/j.biombioe.2012.06.038.

How is rainforest loss really contributing to climate change? 2020. [Online] https:/greenismything. com/2012/12/05/how-is-rainforest-loss-really-contributing-to-climate-change [Accessed: 2021-07-10].

IEA 2018. Brazil. [Online] https://www.iea.org/countries/brazil [Accessed: 2021-07-10].

IRENA 2019. Renewable Power Generation Costs in 2019. [Online] https://www.irena.org/publications/2020/Jun/Renewable-Power-Costs-in-2019 [Accessed: 2021-07-10].

Karp et al. 2021 - Karp, S., Medina, J.D.C., LetTi, L., Woiciechowski, A.L., DE Carvalho, J.C., Schmitt, C., Penha, R.O., Kumlehn, G.S. and Soccol, C. 2021. Bioeconomy and biofuels: the case of sugarcane ethanol in Brazil. Biofuels, Bioproducts and Biorefining 15(3), pp. 899-912, DOI: 10.1002/ bbb. 2195 .

KLUG et al. 2013 - Klug, M., GamboA, N. and Lorber, K. 2013. Sustainable Development and Renewable Energy from Biomass in Peru - Overview of the Current Situation and Research with a Bench Scale Pyrolysis Reactor to Use Organic Waste for Energy Production. Journal of Sustainable Development 6(8), DOI: $10.5539 /$ jsd.v6n8p130.

KPMG 2019. Development of Renewable Energy in Argentina. Energy and Natural Resources. [Online] https://assets.kpmg/content/dam/kpmg/ar/pdf/development-renewable-energy-argentina-2019.pdf [Accessed: 2021-07-10].

LAMARCA, K. 2011. Renewable Energy Initiatives: A Look at Argentina and Law. 26, 190, 17 LAW \& BUS. REV. AM. 583. [Online] https://scholar.smu.edu/lbra/vol17/iss3/7 [Accessed: 2021-07-10].

Lamers et al. 2008 - Lamers, P., McCormick, K. and HiLbert, J.A. 2008. The emerging liquid biofuel market in Argentina: Implications for domestic demand and international trade. Energy Policy 36(4), pp. 1479-1490, DOI: 10.1016/j.enpol.2007.12.023.

LoAYZA et al. 2019 - LoAYZA, N., Villa, E. and MisAs, M. 2019. Illicit activity and money laundering from an economic growth perspective: A model and an application to Colombia. Journal of Economic Behavior and Organization 159, pp. 442-487.

LuCAS et al. 2020 - LuCAS, H., DEL Río, P. and CABEZA, L.F. 2020. Stand-alone renewable energy auctions: The case of Peru. Energy for Sustainable Development 55, pp. 151-160, DOI: 10.1016/j. esd.2020.01.009.

Lopes et al. 2016 - Lopes, M.L., De Lima Paulillo, S.C., Godoy, A., Cherubin, R.A., Lorenzi, M.S, Carvalho Giometti, F.H., Bernardino, D.C., De Amorim Neto, H.B. and De Amorim, H.V. 2016. 
Ethanol production in Brazil: a bridge between science and industry. Brazilian Journal of Microbiology 47, DOI: $10.1016 /$ j.bjm.2016.10.003.

MÁRqueZ, F.B. 2019. The presence of Chinese businesses in the world. Journal of Evolutionary Studies in Business 4(2), pp. 1-12, DOI: 10.1344/jesb2019.2.j058.

Massi, E. and SinGH, J.N. 2018. Industrial policy and state-making: Brazil's attempt at oil-based industrial development. Third World Quarterly 39(6), pp. 1133-1150, DOI: 10.1080/01436597.2018.1455144.

Melo-Becerra et al. 2020 - Melo-Becerra, L.A., Parrado-Galvis, L.M., Ramos-Forero, J.E. and ZaRATE-SOLANO, H.M. 2020. Effects of booms and oil crisis on Colombian Economy: A time-varying vector autoregressive approach. Revista Economía Del Rosario 23(1), pp. 31-63, DOI: 10.12804/revistas. urosario.edu.co/economia/a.8631.

Milaré et al. 2021 -Milaré, É., Milaré, L.T., Loures, F.R., Mattei, J.F., Artigas, P., Borges Franco, R.M., De Morais, R.J. and Advogados, M. 2021. Environmental law and practice in Brazil: overview. [Online] https://uk.practicallaw.thomsonreuters.com/w-014=7503-?transitionType=Default\&contextData(sc.Default)\&firstPage=true [Accessed: 2021-07-10].

Mohtasham, J. 2015. Review Article-Renewable Energies. Energy Procedia 74, pp. 1289-1297, DOI: 10.1016/j.egypro.2015.07.774.

Mzimela et al. 2018 - Mzimela, Z, Mochane, M.J. And Motaung, T.E. 2018. Sugarcane bagasse waste management. Waste-to-Profit? (W-t-P): Value Added Products to Generate Wealth for a Sustainable Economy 1, pp. 293-302.

NDC 2020. Actualización de la Contribución Determinada a Nivel Nacional de Colombia (NDC). [Online] https://www4.unfccc.int/sites/ndcstaging/PublishedDocuments/Colombia\%20First/NDC\%20actualizada\%20de\%20Colombia.pdf [Accessed: 2021-07-10] (in Spanish).

Neves, E.M.S.C. 2016. Institutions and environmental governance in Brazil: the local governments' perspective. Revista de Economia Contemporânea 20(03), DOI: 10.1590/198055272035.

Notton et al. 2011 - Notton, G., Diaf, S. and Stoyanov, L. 2011. Hybrid Photovoltaic/Wind Energy Systems For Remote Locations. Energy Procedia 6, pp. 666-677, DOI: 10.1016/j.egypro.2011.05.076.

Oehlmann et al. 2021 - Oehlmann, M., Glenk, K., Lloyd-Smith, P. and Meyerhoff, J. 2021. Quantifying landscape externalities of renewable energy development: Implications of attribute cut-offs in choice experiments. Resource and Energy Economics 65, 101240, DOI: 10.1016/j.reseneeco.2021.101240.

Quadrado et al. 2021 - Quadrado, G.P., Dillenburg, S., Goulart, E. and Barboza, E.G. 2021. Historical and geological assessment of shoreline changes at an urbanized embayed sandy system in Garopaba, Southern Brazil. Regional Studies in Marine Science 42, 101622, DOI: 10.1016/j.rsma.2021.101622.

Palacio, P. 2020. COVID-19 and the Economic Crisis in Argentina. [Online] https://www.e-ir. info/2020/07/21/covid-19-and-the-economic-crisis-in-argentina [Accessed: 2021-07-10].

Palacio-Ciro, S. and Vasco-Correa, C.A. 2020. Biofuels policy in Colombia: A reconfiguration to the sugar and palm sectors? Renewable and Sustainable Energy Reviews 134, 110316, DOI: 10.1016/j. rser.2020.110316.

Pimentel et al. 2002 - Pimentel, D., Herz, M., Glickstein, M., Zimmerman, M., Richard A., Becker, K., Evans, J., Hussain, B., Sarsfeld, R., Grosfeld, A. and Seidel, T. 2002. Renewable Energy: Current and Potential Issues. BioScience 52(12), pp. 1111-1120, DOI: 10.1641/0006-3568(2002)052[1111:RECAPI]2.0.CO;2.

Pupo-Roncallo et al. 2020 - Pupo-Roncallo, O., Campillo, J. and Ingham, D. 2020. Renewable energy production and demand dataset for the energy system of Colombia. Data in Brief 28. 105084, DOI: 10.1016/j.dib.2019.105084.

SCHAube, P. 2015. The Argentine power system: current challenges and perspectives for the development of renewable energy. AAIQ, Asociación Argentina de Ingenieros Químicos - CSPQ, pp. 1-19, DOI: 10.13140/RG.2.1.4462.5763. 
The Energy Year 2014. Peru 2014-2025 energy plan released. [Online] https://theenergyyear.com/news/ peru-2014-2025-energy-plan-released/?cn-reloaded=1 [Accessed: 2021-07-10].

The Oxford Institute for Energy Studies 2014. Challenges across Brazil's oil sector and prospects for future production. [Online] https://www.oxfordenergy.org/wpcms/wp-content/uploads/2014/10/WPM-55.pdf [Accessed: 2021-07-10].

Timilsina et al. 2013 - Timilsina, G.R, Chisari, O. and Romero, C.A. 2013. Economy-wide impacts of biofuels in Argentina. Energy Policy 55, pp. 636-647, DOI: 10.1016/j.enpol.2012.12.060.

Wainwright, T. 2016. Narconomics: How to Run a Drug Cartel. New York, NY: PublicAffairs, 278 Pages.

Wane et al. 2020 - Wane, A, Cesaro, J.D., Duteurtre, G., Touré, I., Ndiaye, A., Alary, V., Juanès, X., Ickowicz, A., Ferrari, S. and Velasco, G. 2020. The economics of pastoralism in Argentina, Chad and Mongolia. Market participation and multiple livelihood strategies in a shock-prone environment. FAO Animal Production and Health Paper No. 182, Rome. FAO \& CIRAD co-edition, DOI: 10.4060/ cb1271en.

Williams, A. and Porter, S. 2006. Comparison of hydropower options for developing countries with regard to the environmental, social and economic aspects. Proceedings of the International Conference on Renewable Energy for Developing Countries-2006. pp. 1-17. [Online] http://files-do-not-link.udc. edu/docs/cere/Williams_Porter.pdf [Accessed: 2021-07-10].

WNN 2020. Macron stresses importance of nuclear energy for France. [Online] https://world-nuclear-news. org/Articles/Macron-stresses-importance-of-nuclear-energy-for-F [Accessed: 2021-07-10].

World Bank 2010. Peru: Overcoming the Barriers to Hydropower. Energy Sector Management Assistance Program (ESMAP) reports; Washington, DC. [Online] https://openknowledge.worldbank.org/handle/10986/17528 [Accessed: 2021-07-10].

World Resources Institute 2020. STATEMENT: Brazil Sets Weak 2030 Emission Reduction Target. [Online] https://www.wri.org/news/statement-brazil-sets-weak-2030-emission-reduction-target [Accessed: 2021-07-10].

Velasquez et al. 2020 - Velasquez, C.E., Fidéllis, B.G.L. e Estanislau, Costa, A.L. and Pereira, C. 2020. Assessment of the French nuclear energy system - A case study. Energy Strategy Reviews 30, 100513, DOI: 10.1016/j.esr.2020.100513.

ZuÑiga-Collazos, A. 2015. Analysis of research and tourism development in Colombia. Espacios 36(18), p. 9. 


\title{
Możliwości zrównoważonego rozwoju energetycznego w Ameryce Łacińskiej: perspektywy i bariery
}

\begin{abstract}
Streszczenie
Zagadnienia zielonej energii i zrównoważonego rozwoju są dziś jednymi z najczęściej dyskutowanych i najważniejszych w obliczu globalnych wyzwań, takich jak globalne ocieplenie, emisje gazów cieplarnianych, degradacja ekologii itp. Pod tym względem zielona energia jest niezbędnym elementem polityki energetycznej kraju. Jednak kryzysy gospodarcze i niestabilność doprowadziły do konieczności stworzenia zrównoważonej gospodarki, a pogodzenie dwóch wspomnianych polityk prowadzi do konieczności ustalenia, czym jest zrównoważona zielona energia. Kwestie zielonej energii są bardzo ważne dla rozwijających się gospodarek, które są ograniczone finansowo. Kraje Ameryki Łacińskiej są jednymi z tych, które borykają się z poważnymi problemami w tej sferze. Artykuł poświęcony jest sformułowaniu tej koncepcji oraz wykazaniu że zrównoważony rozwój energetyki jest indywidualny dla każdego kraju. Zakres badań obejmuje region Ameryki Łacińskiej po 2000 roku. Autorzy przeprowadzili analizę regresji PKB kilku krajów, a mianowicie Brazylii, Argentyny, Peru i Kolumbii oraz ich sektorów zielonej energii, a także sformułowali wnioski dotyczące zrównoważonych źródeł energii w tych krajach. Podstawowe wyniki badań wskazują, że w każdym z badanych krajów istnieją zrównoważone źródła energii oraz strategie poprawy wydajności sektora energii odnawialnej w tych krajach. Nowością artykułu jest zastosowana metodologia oraz koncepcja zrównoważonej energii odnawialnej.
\end{abstract}

SŁowA KLUCZOWE: Zielona energia, zrównoważona energia odnawialna, Brazylia, Argentyna, Peru, Kolumbia 